\title{
The Potential of Nano Curcumin in Preventing the Formation of Artificial Antisperm Antibody in Wistar Rats through Inflammatory Pathway Regulation
}

\author{
Didit Pramudhito $^{1,2 *}$, Suwandi Sugandi ${ }^{3,4}$, Ida Parwati ${ }^{5,6}$, Muchtan Sujatno ${ }^{7,8}$, Soetojo Soetojo ${ }^{9,10}$ \\ ${ }^{1}$ Department of Surgery, Faculty of Medicine, Universitas Sriwijaya, Palembang, Indonesia; ${ }^{2}$ Department of Surgery, Dr. \\ Mohammad Hoesin General Hospital, Palembang, Indonesia; ${ }^{3}$ Department of Surgery, Faculty of Medicine, Universitas \\ Padjadjaran, Bandung, Indonesia; ${ }^{4}$ Department of Surgery, Hasan Sadikin General Hospital, Bandung, Indonesia; ${ }^{5}$ Department \\ of Clinical Pathology, Faculty of Medicine, Universitas Padjadjaran, Bandung, Indonesia; ${ }^{6}$ Department of Clinical Pathology, \\ Hasan Sadikin General Hospital, Bandung, Indonesia; ${ }^{7}$ Department of Pharmacology, Faculty of Medicine, Universitas \\ Padjadjaran, Bandung, Indonesia; ${ }^{8}$ Department of Pharmacology, Hasan Sadikin General Hospital, Bandung, Indonesia; \\ ${ }^{9}$ Department of Urology, Faculty of Medicine, Universitas Airlangga, Surabaya, Indonesia; ${ }^{10}$ Department of Urology, Soetomo \\ General Hospital, Surabaya, Indonesia
}

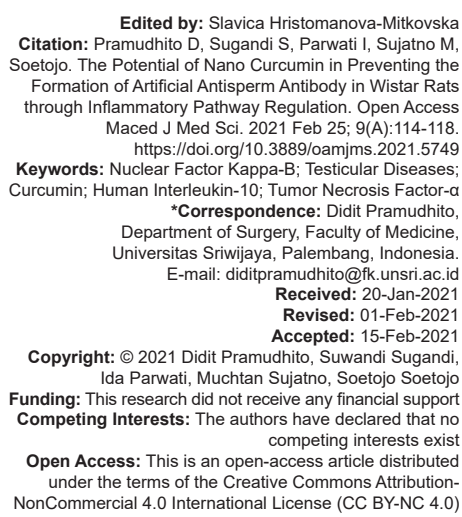

Citation: Pramudhito D, Sugandi S, Parwati I, Sujatno M

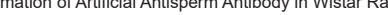
Maced J Med Sci. 2021 Feb 25; 9(A):114-118. ar Factor Kappa-B; Testicular Disease: *Correspondence: Didit Pramudhito, sitas Sriwijaya, Palembang, Indonesia. . Received: 20-Jan-202 Copyright: ๑ 2021 Didit Pramudhito, Suwandi Sugandi, unding: This research did not receive any financial support NonCommercial 4.0 International License (CC BY-NC 4.0)

\section{Abstract}

BACKGROUND: Immunological mechanisms of infertility are still poorly understood and controversial, both the cause and treatment. Inflammation, immunology, cell proliferation, cell differentiation, and cell survival are influenced by several proteins, including nuclear factor kappa-B (NFKB), tumor necrosis factor- $\alpha$ (TNF- $\alpha$ ), and interleukin-10 (IL-10)

AIM: This study aimed to explore the potential of nano curcumin to prevent anti-sperm antibodies (ASA) formation due to the testes' inflammatory process in Wistar rats.

METHODS: This research is an experimental study with a pre-post-test approach with control group. The research subjects were rats (Rattus norvegicus) of the Wistar strain. The induced animals were grouped into three groups: Group 1 received nano curcumin $1 \times 80 \mathrm{mg} / \mathrm{kg} \mathrm{BW}$ orally, Group 2 received dexamethasone $1 \times 0.3 \mathrm{mg} / \mathrm{kg} \mathrm{BW}$, and Group 3 received placebo aquadest $1 \times 1 \mathrm{~mL}$ orally. TNF- $\alpha, \mathrm{NF}-\mathrm{kB}$, and IL10 levels in serum were examined with enzyme-linked immunosorbent assay.

RESULTS: The nano curcumin treatment showed the ability to reduce the pro-inflammatory cytokine protein TNF- $a$ expression $(47.3 \pm 2.32)$ more optimally than dexamethasone treatment $(54.4 \pm 3.22)$. Nano curcumin has also shown the ability to reduce the pro-inflammatory cytokine transcription factor, NF-kB $(32.5 \pm 2.76)$ more optimally than treatment with dexamethasone $(44.6 \pm 2.43)$.

CONCLUSION: Nano curcumin can prevent the formation of ASA in testicular trauma through inhibition of the inflammatory response.

\section{Introduction}

Infertility is defined as not getting pregnant after 1 year of regular sexual intercourse without contraception. Both male and female factors can cause infertility [1], [2]. The causes of male infertility can be grouped into congenital disorders, urogenital tract infections, varicocele, endocrine disorders, and genetic and immunological disorders. The prevalence of infertility is $15 \%$ in couples after 1 year of regular sexual intercourse without contraception. The etiologies of male infertility were idiopathic semen abnormalities $(75 \%)$, varicocele $(12 \%)$, urogenital infection $(6 \%)$, and immunological factors (3\%) [2]. The American Urological Association and the American Medical Reproductive Association recommend evaluating infertility before 1 year if there is a risk factor for male infertility, namely, bilateral cryptorchidism. Moreover, risk factors for female infertility was age over 35 years [2].
A variety of conditions that can affect infertility are cryptorchidism, post-pubertal mumps orchitis, testicular torsion, and trauma. Testicular torsion and testicular trauma cause testicular atrophy, resulting in anti-sperm antibodies (ASA), affecting sperm function and motility [3], [4]. Strong attachments of the Sertoli cells, create the blood testicular barrier (BTB), preventing the immune system from communicating with post-mitotic germ cells. Under certain conditions such as testicular torsion, vasectomy, and trauma to the testicular walls, this can be damaged by $B T B$ resulting in an immune/inflammatory response to the sperm, which is shown as ASA. The clinical importance of cancer clinical trials is after puberty because antigens on germ cells that occur during meiosis occur only after puberty. Pre-pubertal testicular damage such as biopsy, torsion, or trauma will not induce ASA [1].

ASA therapy in two ways, first by suppressing the formation of antibodies, and the second is Assisted 
Reproductive Technique by removing antibodies attached to sperm or selecting sperm without antibodies. Corticosteroids that have anti-inflammatory effects have become drugs used to suppress the formation of ASA. There are several opinions regarding the efficacy of corticosteroids to treat ASA with different doses and administration duration [3], [4].

Immunological mechanisms of infertility are still poorly understood and controversial, both the cause and treatment [5], [6]. Inflammation, immunology, cell proliferation, cell differentiation, and cell survival are influenced by several proteins including nuclear factor kappa-B (NFkB), tumor necrosis factor- $\alpha$ (TNF- $\alpha)$, and interleukin-10 (IL-10) [5]. NFKB is a transcription factor that resides in the cytoplasm of every cell and moves to the nucleus when activated. Activation is caused by various agents, including stress, cigarette smoke, bacterial viruses, inflammatory stimuli, cytokines, free radicals, carcinogens, tumor promoters, and endotoxins. On activation, NFKB regulates the expression of more than 400 different genes consisting of enzymes (cyclooxygenase-2, 5-lipoxygenase, and inducible nitric oxide synthase), cytokines (TNF- $\alpha, \mathrm{IL}-1, \mathrm{IL}-6$, IL-8, and chemokines), molecules adhesions, cell cycle controlling molecules, viral proteins, and angiogenic factors. NFKB is primarily associated with a wide variety of human diseases, including asthma, atherosclerosis, AIDS, rheumatoid arthritis, diabetes, osteoporosis, Alzheimer's, and cancer. Several substances are known to suppress NFKB, namely, cytokines from $\mathrm{T}$ helper 2 (IL-4, IL-13, and IL-10), interferon, endocrine hormones, phytochemicals, corticosteroids, and immunosuppressants [5], [6].

Materials from phytopharmacy can affect the activation of $\mathrm{NFKB}$, and cytokines, namel, curcumin. Curcumin is one of the bioactive compounds from Curcuma (Curcuma xanthorrhiza Roxb.) which has the formula $\mathrm{C}_{21} \mathrm{H}_{20} \mathrm{O}_{6}$ [7], [8]. Curcuma is one of the plants used for Indonesian traditional medicine for a long time. In 1995, Singh and Aggarwal first published curcumin to inhibit NFkB through inhibition before inhibitor of kappa B alpha (IKBa) phosphorylation using human monoblastic leukemia cell cultures [8].

The bioavailability of curcumin is low because less absorption (5\%) rapidly metabolized and eliminated. Curcumin is produced in nanosize to increase its absorption. Nano curcumin is also soluble in water [9]. From several studies, nano curcumin was found in plasma with maximum levels after $4 \mathrm{~h}$ of oral administration [9], [10]. In the in vitro study, the results were the same as regular curcumin, but in the in vivo study, the level of nano curcumin in rat brain was increased $96 \%$ compared to ordinary curcumin. This study is the first study that explores the potential of nano curcumin preparations to prevent ASA formation due to the inflammatory process of the testes in Wistar rats. This study will assess the efficacy of nano curcumin in suppressing inflammatory cytokine responses.

\section{Methods}

\section{Animal}

This research is an experimental study with a pre-post-test approach with control group. The research subjects were rats (Rattus norvegicus) of the Wistar strain obtained from the Eureka Research Laboratory, Indonesia and were declared healthy and fit to be research subjects. A total of 30 male rats weighing $200 \mathrm{~g} \pm 20 \mathrm{~g}$, aged 10-11 weeks, were placed in cages under controlled conditions (12 $\mathrm{h}$ light and dark cycle with a temperature of $22 \pm 1^{\circ} \mathrm{C}$ and humidity of $40-60 \%$ ), food, and drink ad libitum. The ethical committee has approved all animal treatments and experimental procedures of the Faculty of Medicine, Universitas Padjadjaran with reference number 126/ UN6.C2.1.2/KEPK/PN.

\section{Nano curcumin}

Nano curcumin is obtained from Miso, Seoul, South Korea. An examination with Delsa Nano (Microtrac, Pennsylvania, US) was used at the pharmacology laboratory of Institut Teknologi Bandung, Indonesia, to determine nano curcumin's size. From these measurements, the mean diameter was 723.6 $\mathrm{nm}$.

\section{Experimental animal treatment}

The experimental animals were induced to testicular tract trauma. Previously, the rat was anaesthetized using $10 \%$ chloral hydrate $(3.5 \mathrm{ml} / \mathrm{kg}$ ) intraperitoneally. Furthermore, orchidectomy was performed on the left testis. The induced animals were grouped into three groups, namely, Group 1 received nano curcumin $1 \times 80 \mathrm{mg} / \mathrm{kg}$ BW orally, Group 2 received dexamethasone $1 \times 0.3 \mathrm{mg} / \mathrm{kg} \mathrm{BW}$ orally; and Group 3 received placebo aquadest $1 \times 1 \mathrm{~mL}$ orally. All treatments were carried out for 7 days.

Furthermore, the rat serum and testicular organ evacuation were carried out with anesthetic using $10 \%$ intraperitoneal chloral hydrate $(3.5 \mathrm{ml} / \mathrm{kg})$. As much as $1 \mathrm{~mL}$ of blood was obtained from the periorbital vein. Then, it was centrifuged at $5000 \mathrm{rpm}$ for $10 \mathrm{~min}$, and the supernatant was separated and stored at $-20^{\circ} \mathrm{C}$. Testicular organs that have been evacuated are inserted into 10\% neutral buffer formalin, then the dehydration process is carried out with alcohol with graded concentrations ranging from alcohol concentrations of $96 \%, 80 \%$, and $70 \%$ and xylene I, II, and III. The paraffinization process is carried out and made into paraffin blocks. Then, the paraffin block was cut with a thickness of $5 \mu \mathrm{m}$ and placed on a coated slide (Biogear®, Singapore). 


\section{Enzyme-linked immunosorbent assay} (ELISA) examination

The TNF- $\alpha, N F-k B$, and IL-10 levels in serum were examined with ELISA TNF- $\alpha$; ELISA NF-kB; and ELISA IL10 (Cloud Clone, Hangzhou, PRC), based on the manufacturer's protocol. Briefly, $50 \mu \mathrm{l}$ of standard diluent or serum sample was added to the well, coated with anti-TNF $\alpha$; anti-NF-kB; anti-IL10; and incubated at $37^{\circ} \mathrm{C}$ for $30 \mathrm{~min}$. After the plates were washed, $100 \mu \mathrm{l}$ of the biotinylated antibody solution was added and incubated for $30 \mathrm{~min}$ at $37^{\circ} \mathrm{C}$. After 3 times washing, $50 \mu \mathrm{L}$ of avidin-peroxidase complex solution were added and incubated for $15 \mathrm{~min}$ at $37^{\circ} \mathrm{C}$. After washing, $50 \mu \mathrm{L}$ of tetramethylbenzidine color solution was added and incubated in the dark for $15 \mathrm{~min}$ at $37^{\circ} \mathrm{C}$. Finally, $50 \mu \mathrm{L}$ stop solution was added to stop the reaction, and the optical density was measured using an ELISA reader (Biorad, Singapore), the wavelength of $450 \mathrm{~nm}$.

\section{Immunohistochemistry examination}

Testicular tissue on coated slides was rehydrated using xylene and alcohol with a concentration of $96 \%, 90 \%, 80 \%$, and $70 \%$ and rinsed with tap water. The next step was carried out with the retrieval antigen using the heat induced epitope retrieval method, where the slides were inserted into a citrate buffer solution, then heated at $95^{\circ} \mathrm{C}$ for $60 \mathrm{~min}$. An artificial ASA was then stained 1:1000 (Cloud Clone, Hangzhou, $\mathrm{PRC}$ ), followed by overnight incubation at $4^{\circ} \mathrm{C}$. The next step was staining with a secondary antibody, biotinylated-horseradish peroxidase, incubation for $1 \mathrm{~h}$, at room temperature. Furthermore, chromogen was administered. Next, the dehydration process was again carried out using a concentration of alcohol and xylene. The mounting and assessing the TNF- $\alpha$ expression using ImageJ software will obtain the TNF- $\alpha$ expression percentage.

\section{Data analysis}

All data were presented as mean \pm standard deviation, and all statistical analyzes were performed with the SPSS 25 (IBM) program. One-way ANOVA followed by post hoc analysis was carried out to assess differences in mean expression levels and levels of each protein and clinical data. $p<0.05$ was determined as an indication that there was a significant difference in mean levels.

\section{Results}

Table 1 compares various inflammatory cytokine levels, such as TNF- $\alpha$ and NF-kB between
Table 1: TNF- $\alpha$, NF-kB, and IL-10 level

\begin{tabular}{|c|c|c|c|}
\hline Variables & Group & Levels $(\mathrm{pg} / \mathrm{mL}) \pm \mathrm{SD}$ & $p$-value ${ }^{*}$ \\
\hline \multirow[t]{3}{*}{ TNF- $\alpha$} & 1 & $47.3 \pm 2.32$ & 0.001 \\
\hline & 2 & $54.4 \pm 3.22$ & 0.001 \\
\hline & 3 & $87.8 \pm 2.39$ & \\
\hline \multirow[t]{3}{*}{ NF-kB } & 1 & $32.5 \pm 2.76$ & 0.001 \\
\hline & 2 & $44.6 \pm 2.43$ & 0.001 \\
\hline & 3 & $76.8 \pm 4.32$ & \\
\hline \multirow[t]{3}{*}{ IL-10 } & 1 & $23.5 \pm 1.31$ & 0.001 \\
\hline & 2 & $33.6 \pm 2.21$ & 0.001 \\
\hline & 3 & $46.8 \pm 2.54$ & \\
\hline
\end{tabular}

the treatment groups. The nano curcumin treatment showed the ability to reduce the pro-inflammatory cytokine protein TNF- $\alpha$ expression more optimally than dexamethasone treatment. Nano curcumin has also shown the ability to reduce the pro-inflammatory cytokine transcription factor, NF-kB, more optimally than treatment with dexamethasone.

Figure 1 shows the comparison of ASA expression in testicular tissue between treatment groups. Treatment with nano curcumin reduced the expression of ASA more optimally than treatment with dexamethasone.

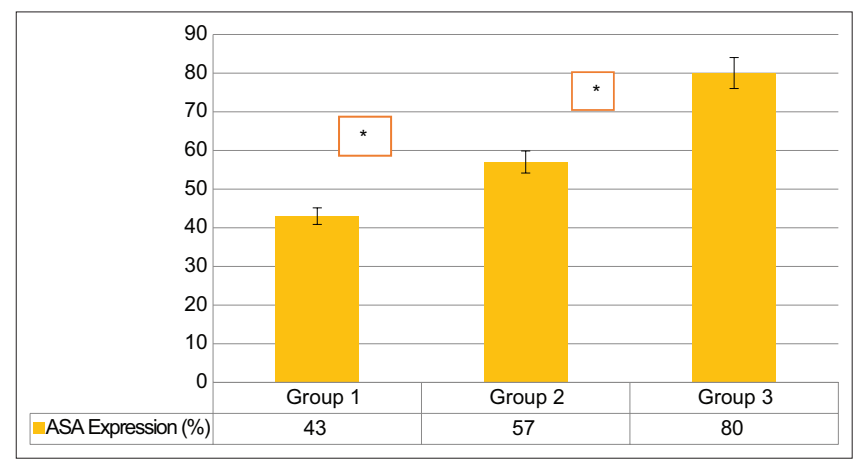

Figure 1: Anti-sperma antibody expression. * $p<0.05$ versus Group 3, ANOVA followed post hoc Bonferroni; 1: Nano curcumin, 2: Dexamethasone, 3: Placebo

\section{Discussion}

TNF- $\alpha$ is a pro-inflammatory cytokine which will increase its level in inflammation and infection [11]. In this study, the damage was occurred to BTB, the barrier that separates the basal and apical compartments of the Sertoli cells [12], [13], [14]. The basal compartment is a mitosis process, whereas in the apical compartment there is a process of meiosis. TNF- $\alpha$ comes from macrophages and Sertoli cells in the testes, increasing in number when there are inflammation and infection [15]. In the nano curcumin group, there was a decrease in TNF- $\alpha$ level lower than dexamethasone and placebo because nano curcumin inhibited TNF- $\alpha$ by blocking the TNF receptor. Research by Wajant et al. founded that expression of TNF- $\alpha$ and TNF- $\alpha$ receptors in the posterior spinal cord was increased in a diabetic rat model [13]. Treatment with curcumin decreases the 
expression of TNF- $\alpha$ and TNF- $\alpha$ receptors. Curcumin reduces exercise-induced inflammation with the result of reducing plasma keratin kinases and reducing levels of inflammatory cytokines IL-1 $\beta$, IL-6, and TNF- $\alpha$ [16]. Research by Bisht et al. stated that administration of nano curcumin could reduce 1.5 times the TNF-a level and 2.4 times the IL- 6 levels found in hepatocellular injury [17]

$\mathrm{NF} K \mathrm{~B}$ in the inactive state is located in the cytoplasm and binds to IKB protein. Increased NFKB activity is associated with its involvement in various cancers in humans. Almost all of the biological effects of curcumin are through gene regulation by $\mathrm{NFKB}_{\mathrm{K}}$, namely, proteins associated with apoptosis (B-cell lymphoma [Bcl]-2, Bcl-X, and TNF receptor-associated factor), cell cycle regulators (cyclin D1 and cyclin D2), growth factors (IL, TNF- $\alpha$, and vascular endothelial growth factor), receptors $\left(\mathrm{CD}_{40}, \mathrm{CD}_{44}, \mathrm{CD}_{86}, \mathrm{CCR}_{7}\right.$, and $\mathrm{CXCL}$ ), and matrix metalloproteinases (MMP-2 and MMP-9) [18], [19], [20]. Research by Bisht et al., nano curcumin inhibits pancreatic cancer cells through NFkB inhibition [17]. From the information above, it can be concluded that nano curcumin inhibits NFKB activation. In this study's results, nano curcumin played a role in inhibiting the activation of NFKB transcription in testicular trauma that damaged BTB to prevent ASA.

\section{Conclusion}

Nano curcumin can prevent the formation of ASA in testicular trauma through inhibition of the inflammatory response.

\section{References}

1. Sabanegh E, Agarwal A. Male infertility. In: Wein AJ, Kavoussi LR, Novick AC, Partin AW, Peters CA, editors. Campbell-Walsh Urology. $10^{\text {th }}$ ed. Philadelphia, PA: Saunders-Elsevier; 2012. p. 616-47. https://doi.org/10.1016/b978-1-4160-6911-9.00021-9

2. Dohle GR, Jungwirth A, Kopa Z, Giwercman A, Diemer T, Hargreave. Male Infertility. The Netherlands: European Association of Urology Guidelines; 2009. p. 6-61. https://doi. org/10.1016/j.eururo.2012.04.048

3. Cooper TG, Aitken J, Auger J, Baker HW, Barratt CL, Behre HM, et al. WHO Laboratory Manual for the Examination of Human Semen and Sperm-Cervical Mucus Interaction. $5^{\text {th }}$ ed. Switzerland: WHO Press; 2010. p. 108-30.

4. Lombardo F, Gandini L, Dondero F, Lenzi A. Antisperm immunity in natural and assisted reproduction. Hum Rep Update. 2001;7(5):450-6.

PMid:11556491

5. Oeckinghaus A, Ghosh S. The NF-kappaB family of transcription factors and its regulation. Cold Spring Harb Perspect Biol. 2009;1(4):a000034.

https://doi.org/10.1101/cshperspect. a000034

PMid:20066092

6. Ahn KS, Aggarwal BB. Transcription factor NF-kappaB: A sensor for smoke and stress signals. Ann N Y Acad Sci. 2005;1056:218-33

PMid: 16387690

7. Asadullah K, Sterry W, Volk HD. Interleukin-10 therapy--review of a new approach. Pharmacol Rev. 2003;55(2):241-69. https:// doi.org/10.1124/pr.55.2.4

PMid:12773629

8. Lin CL, Lin JK. Curcumin: A potential cancer chemopreventive agent through supressing NF-KB signaling. J Cancer Mol. 2008;4(1):11-6.

9. Tsai YM, Chien CF, Lin LC, Tsai TH. Curcumin and its nanoformulation: The kinetics of tissue distribution and blood-brain barrier penetration. Int J Pharm. 2011;416(1):331-8. https://doi. org/10.1016/j.jijpharm.2011.06.030

PMid:21729743

10. Bisht S, Feldmann G, Soni S, Ravi R, Karikar C Maitra A, et al. Polymeric nanoparticle-encapsulated curcumin ("nanocurcumin"): A novel strategy for human cancer therapy. J Nanobiotechnol. 2007;5:3. https://doi. org/10.1186/1477-3155-5-3

PMid: 17439648

11. Huxford T, Ghosh G. A structural guide to proteins of the NF-kappaB signaling module. Cold Spring Harb Perspect Biol. 2009;1(3):a000075. https://doi.org/10.1101/cshperspect. a000075

\section{PMid:20066103}

12. Lawrence T. The nuclear factor NF-kappaB pathway in inflammation. Cold Spring Harb Perspect Biol. 2009;1(6):a001651. https://doi.org/10.1101/cshperspect. a001651

PMid:20457564

13. Wajant $\mathrm{H}$, Pfizenmaier $\mathrm{K}$, Scheurich. Tumor necrosis factor signaling. Cell Death Differ. 2003;10(1):45-65. https://doi. org/10.1038/sj.cdd.4401189

PMid:12655295

14. Mosser DM, Zhang X. Interleukin-10: New perspectives on an old cytokine. Immunol Rev. 2008;226:205-18.

PMid:19161426

15. Mocellin S, Marincola FM, Young HA. Interleukin-10 and the immune response against cancer: A counterpoint. J Leukoc Biol. 2005;78(5):1043-51. https://doi.org/10.1189/jlb.0705358 PMid: 16204623

16. Turek PJ. Male reproductive physiology. In: Wein AJ, Kavoussi LR, Novick AC, Partin AW, Peters CA, editors. Campbell-Walsh Urology. $10^{\text {th }}$ ed. Philadelphia, PA: Saunders-Elsevier; 2012. p. 591-615. https://doi.org/10.1016/ b978-1-4160-6911-9.00020-7

17. Bisht S, Khan MA, Bekhit M, Bai H, Cornish T, Mizuma M, et al. A polymeric nanoparticle formulation of curcumin (NanoCurc ${ }^{\mathrm{TM}}$ ) ameliorates $\mathrm{CCl}$-induced hepatic injury and fibrosis through reduction of pro-inflammatory cytokines and stellate cell activation. Lab Invest. 2011;91(9):1383-95. https:// doi.org/10.1038/labinvest.2011.86

PMid:21691262

18. Cheng CY, Mruk DD. The blood-testis barrier and its implications for male contraception. Pharmacol Rev. 2012;64(1):16-64. https://doi.org/10.1124/pr.110.002790 PMid:22039149

19. Li MW, Mruk DD, Lee WM, Cheng CY. Cytokines and junction restructuring events during spermatogenesis in the 
testis: An emerging concept of regulation. Cytokine Growth Factor Rev. 2009;20(4):329-38. https://doi.org/10.1016/j. cytogfr.2009.07.007

PMid:19651533

20. Wong EW, Mruk DD, Lee WM, Cheng CY. Regulation of blood-testis barrier dynamics by TGF-beta3 is a Cdc42dependent protein trafficking event. Proc Natl Acad Sci U S A. 2010;107(25):11399-404. https://doi.org/10.1073/ pnas. 1001077107

PMid:20534521 